\title{
OPEM
}

www.opem.org

Oriental Pharmacy and Experimental Medicine 2009 9(4), 285-291

DOI 10.3742/OPEM.2009.9.4.285

\section{The protective effect of anti-oxidant in cadmium-induced hair cell death}

\author{
Su-Jin Kim ${ }^{1,3}$, No-Yil Myung ${ }^{1}$, Hyun-Ja Jeong ${ }^{2}$, Jae-Young Um ${ }^{1}$, Hyung-Min Kim ${ }^{1}$ and Seung-Heon \\ Hong ${ }^{3, *}$ \\ ${ }^{l}$ College of Oriental Medicine, Institute of Oriental Medicine, Kyung Hee University, 1 Hoegi-Dong, Dongdaemun-Gu, \\ Seoul, 130-701, Republic of Korea ; ${ }^{2}$ Biochip Research Center, Hoseo University, 165 Sechul-ri, Baebang-myun, \\ Asan, Chungnam, 336-795, Republic of Korea: ${ }^{3}$ Wonkwang-Oriental Medicines Research Institute and College of \\ Pharmacy, Wonkwang University, Iksan, Jeonbuk, 570-749, Republic of Korea
}

Received for publication March 04, 2009; accepted March 13, 2009

\begin{abstract}
SUMMARY
Cadmium $\left(\mathrm{Cd}^{2+}\right)$ is a heavy metal and a potent carcinogen implicated in tumor development through occupational and environmental exposure. However, the auditory effect of $\mathrm{Cd}^{2+}$ is not poorly understood. The purpose of the present study was to investigate whether prevent the ototoxic effects of $\mathrm{Cd}^{2+}$ by antioxidnat in auditory cell line, HEI-OC1. Rosmarinic acid is a naturally occurring phenolic compound and also known to possess marked antioxidant properties. We showed that antioxidnat inhibited the the cytochrome c release induced by $\mathrm{Cd}^{2+}$. In addition, we showed that the regulatory effect of antioxidnat on apoptosis is through the caspase- 9 activation, and extracellular signal-regulated kinase activation in auditory cells. These results suggested antioxidnat its therapeutic usefulness, against $\mathrm{Cd}^{2+}$ induced activation of caspase-9 and ERK.
\end{abstract}

Key words: Cadmium; Antioxidant; Reactive oxygen species; Extracellular signal-regulated kinase

\section{INTRODUCTION}

Cadmium $\left(\mathrm{Cd}^{2+}\right)$ is a nonessential element that is widely used in industry, and is also found as a contaminant in many agricultural products (De Vries et al., 2007). $\mathrm{Cd}^{2+}$ contamination of the soil and water have raised concern because this metal bioaccumulates in the upper levels of the food chain, including in humans (Satarug et al., 2003). Given its current rate of release into the environment, the $\mathrm{Cd}^{2+}$ content in the human body is likely to

\footnotetext{
*Correspondence: Seung-Heon Hong, Wonkwang-Oriental Medicines Research Institute and College of Pharmacy, Wonkwang University, Iksan, Jeonbuk, 570-749, Republic of Korea. Tel: +82638506805; fax: +82638433421; E-mail: jooklim@wonkwang.ac.kr
}

increase in the future and it has genetoxic effect (Bertin et al., 2006), which can lead to a higher incidence of $\mathrm{Cd}^{2+}$-related diseases. The liver and kidneys have traditionally been considered the main targets of $\mathrm{Cd}^{2+}$ toxicity (Horiguchi et al., 2006; Nishijo et al., 2006). Recently, it was reported that hair cells are more sensitive to cadmium than kidney tubule cells, and that the cochlear component of hearing is more vulnerable to cadmium toxicity than the other parts of the auditory system (Ozcaglar $e t$ al., 2001).

Apoptosis plays not only an essential role in development and tissue homeostasis but is also involved in a wide range of pathological conditions (De Martinis et al., 2007; Gatzka and Walsh 2007; Van Heemst et al., 2007). In mammalian cells, there 
are two major caspase activation pathways: the extrinsic and intrinsic pathways. In the extrinsic pathway, binding of the death receptors causes the activation of caspase-8, which is an initiator caspase. In the intrinsic pathway, various forms of cellular stress cause mitochondrial alterations leading to mitochondrial membrane depolarization (MMP) and the release of cytochrome c (cyt c). In the cytosol, cyt c binds to and activates Apaf-1, which then activates pro-caspase-9. Active caspase- 9 directly cleaves and activates the effector protease, caspase- 3 . The apoptotic pathway induced by $\mathrm{Cd}^{2+}$ is controversial. Some studies strongly suggest that caspases play a key role in $\mathrm{Cd}^{2+}$-induced cell death (Kim et al., 2000; Li et al., 2000; Kondoh et al., 2002), whereas other studies suggest that $\mathrm{Cd}^{2+}$ induced the apoptosis through caspase-independent pathway (Harstad and Klaassen 2002; Shih et al., 2003; Lemarie et al., 2004). This apparently conflicting data suggests that the pathways of $\mathrm{Cd}^{2+}$-induced apoptosis differ according to the cell type or the exposure (cell treatment) conditions.

Mitogen-activated protein kinases (MAPKs) belong to a family of Ser/Thr protein kinases that transmit extracellular signals into the nucleus. There are three subfamilies of MAPKs including c-Jun NH2terminal kinase (JNK; also known as stress-activated protein kinase), p38 MAPK, and extracellular signalrelated kinase (ERK) (Schaeffer et al., 1999). In general, the ERK signaling cascade is activated by growth factors and is associated with cell survival and proliferation (Lewis et al., 1998; Puddicombe et al., 2000). On the other hand, p38 and JNK are mainly activated by cellular stress and are often associated with inflammation and apoptosis. However, cumulative reports have indicated that these signaling pathways exhibit more complex roles in the regulation of distinct cellular effects. The cellular functions regulated by ERK, p38 or JNK seem to depend on the cell type, the stimulus, the duration and strength of kinase activities.

Rosmarinic acid (RA) is a naturally occurring phenolic compound. RA is an ester of caff eic acid and 3,4-dihydroxyphenyllactic acid (Scarpati and Oriente, 1958) This compound is also known to possess marked antioxidant properties, acting as a reactive oxygen species scavenger and lipid peroxidation inhibitor (Kosar et al., 2008). However, the protective effect of RA as an antioxidant on the auditory system is not completely understood. Thus, the aim of the present study was to investigate the ability of RA to prevent ototoxicity induced by $\mathrm{Cd}^{2+}$ in auditory cell lines, HEI-OC1 cells.

\section{MATERIALS AND METHODS}

\section{Reagents}

Fetal bovine serum, and high-glucose Dulbecco's modified Eagle's medium (DMEM) were purchased from GIBCO BRL (Grand Island, NY, USA). Dimethyl sulfoxide (DMSO), 3-(4,5-dimethylthiazol-2-yl)-2,5diphenyltetrazolium bromide (MTT) and other reagents were purchased from Sigma Chemical(St. Louis, MO, USA). Anti-human caspase-9, ERK, and cyt $c$ antibody was obtained from Santa Cruz Biotechnology, Inc. (Santa Cruz, CA, USA). The caspase assay kits were supplied by $\mathrm{R} \& \mathrm{D}$ system Inc. (Minneapolis, USA).

\section{Cell culture}

The HEI-OC1 cell line was kindly donated by Dr. Federico Kalinec (House Ear Institute, LosAngeles, CA, USA). According to the report by Dr. Federico, establishment of immortal cell lines has been facilitated by the development of a transgenic mouse, Immortomouse $^{\mathrm{TM}}$, which harbors a temperaturesensitive mutant of the SV40 large T antigen gene under the control of an interferon-r-inducible promoter element. Cochlear half turns from Immortomice (Charles River Laboratories, Wilmington, MA, USA) at postnatal day 7 were cultured on uncoated plastic cultures dishes under permissive conditions $\left(33^{\circ} \mathrm{C}\right)$ in DMEM (Gibco-BRL, Grand Island, NY, USA) containing $10 \%$ fetal bovine serum (JRH BIOSCIENCE, Lenexa, KS, USA) and $50 \mathrm{U} / \mathrm{ml} \mathrm{r-}$ interferon without antibiotics.Cochlear explants 
were moved to non-permissive conditions $\left(39^{\circ} \mathrm{C}\right.$, $\left.5 \% \mathrm{CO}_{2}\right)$ at different periods and allowed to differentiate for up to 180 days. Cultures were monitored on a daily basis by phase-contrast and video microscopy. Cells growing in the region formerly associated with the organ of corti were isolated by lifting them with a micropipette after a $2.5 \mathrm{~min}$ incubation of the explants with trypsinEDTA. A cell line, termed HEI-OC1, was cloned using the limiting dilution method and characterized by phase-contrast light microscopy, Western blotting and immunofluorescence analysis. No antibiotics were used at any step of the cloning. HEI-OC1 cells, which express several molecular markers characteristic of the organ of corti sensory cells $(\alpha-$ thyroid hormone, brain-derived neurotrophic factor, calbindin, calmodulin, Connexin 26, Math 1, Myosin 7a, organ of Corti protein 2, and prestin at permissive condition.), are extremely sensitive to ototoxic drugs. HEI-OC1 cells were cultured under permissive condition: $33^{\circ} \mathrm{C}, 10 \% \mathrm{CO}_{2}$ in DMEM supplemented ( $8 \mathrm{ml}$ for $100 \mathrm{~mm}$ dish) with $10 \%$ fetal bovine serum. Cells were grown until they were $80.90 \%$ confluent. Confluent cells were incubated with various concentrations of chemicals. HEI-OC1 was cloned from cochlear explants via pathway of different culture stages (permissive condition and non-permissive condition). Cloned $\mathrm{HEI}-\mathrm{OC} 1$ cells growing under permissive conditions $\left(33^{\circ} \mathrm{C}, 10 \% \mathrm{CO}_{2}\right)$ express nestin, which suggests that they could retain multipotential stem cell properties (Kalinec et al., 2003). Nestin makes HEIOC1 cells retain their cell division activity.

\section{Measurement of caspase-9 activity}

The enzymatic activity of caspase- 3 was assayed using a caspase colorimetric assay kit (R\&D Systems) according to the manufacturer's protocol. Briefly, the cells were treated with CSCYT, then lysed in a lysis buffer. The lysed cells were centrifuged at $14,000 \mathrm{rpm}$ for $5 \mathrm{~min}$. The protein supernatant was incubated with reaction buffer $(50 \mu \mathrm{l})$ and caspase substrate $(5 \mu \mathrm{l})$ at $37^{\circ} \mathrm{C}$ for $2 \mathrm{~h}$. The absorbance was measured using a plate reader at a wavelength of $405 \mathrm{~nm}$. Equal amounts of the total protein from each lysate were quantified using a bicinchoninic acid protein quantification kit (Sigma).

\section{Western blot analysis}

For analysis of the levels of cyt $c$, caspase-9, ERK, and $\mathrm{p}$-ERK, stimulated cells were rinsed twice with ice-cold PBS and were then lysed in ice-cold lysis buffer (1\% Triton, $1 \%$ Nonidet P-40, $0.1 \%$ SDS, $1 \%$ deoxycholate in PBS). Cell lysates were centrifuged at $15,000 \mathrm{~g}$ for $5 \mathrm{~min}$ at $4^{\circ} \mathrm{C}$; the supernatant was then mixed with an equal volume of $2 \times$ SDS sample buffer, boiled for $5 \mathrm{~min}$, and then separated through 10\% SDS-PAGE gels. After electrophoresis, the protein was transferred to nylon membranes by electrophoretic transfer. The membranes were blocked in $5 \%$ skim milk for $2 \mathrm{~h}$, rinsed, and incubated overnight at $4^{\circ} \mathrm{C}$ with primary antibodies in PBS/ $0.5 \%$ Tween 20 . Excess primary antibody was then removed by washing the membranes four times in PBS/0.5\% Tween 20, and the membranes were incubated for $1 \mathrm{~h}$ with HRP-conjugated secondary antibodies (against mouse, goat, or rabbit). After three washes in PBS/0.5\% Tween 20, the protein bands were visualized by an enhanced chemiluminesence assay (Amersham Pharmacia Biotech, NJ, USA) following the manufacturer's instructions.

\section{Statistical analysis}

The experiments shown are a summary of the data from at least-three experiments and are presented as the mean \pm S.E.M. Statistical evaluation of the results was performed by ANOVA with Tukey post hoc test. The results were considered significant at a value of $P<0.05$.

\section{RESULTS}

The effect of RA on cyt c release in HEI-OC1 cell lines Cyt $\mathrm{c}$ is released after mitochondrial membrane permeabilization, and induces apoptosis (Garrido et al., 2006). Western blot analysis was performed 


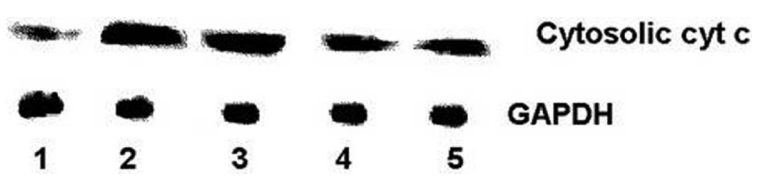

Fig. 1. The Effect of RA on cyt $c$ release. Cells $\left(5 \times 10^{6} /\right.$ well) were preincubated for $2 \mathrm{~h}$ with RA $(1-100 \mathrm{mM})$ and then treated with $\mathrm{Cd}^{2+}(10 \mathrm{mM})$ for $24 \mathrm{~h}$, and then the cyt $c$ was determined by Western blot analysis. 1) Control; 2) $\mathrm{Cd}^{2+}$ treatment; 3) RA $\left.(1 \mathrm{mM})+\mathrm{Cd}^{2+} ; 4\right) \mathrm{RA}$ $\left.(10 \mathrm{mM})+\mathrm{Cd}^{2+} ; 5\right) \mathrm{RA}(100 \mathrm{mM})+\mathrm{Cd}^{2+}$.

to assay the effect of RA on the release of cyt c induced by $\mathrm{Cd}^{2+}$. The results showed that $\mathrm{Cd}^{2+}$ treatment increased cyt c levels in the cytosol, but RA suppressed the induction the cyt $\mathrm{c}$ levels (Fig. 1A). The relative expression level of cyt $c$ was measured using an image analyzer (Fig. 1B).

\section{The effect of RA on caspase-9 activation in HEI-OC1 cell lines}

To investigate whether RA regulate the caspase-9 activation, we performed the Western blot analysis. Cells were pretreated with RA (1-100 mM) for $2 \mathrm{~h}$, and then treated with $\mathrm{Cd}^{2+}(10 \mu \mathrm{M})$ for $24 \mathrm{~h}$. The results showed that $\mathrm{Cd}^{2+}$ reduced the pro-caspase9 expression, which is an inactive form of caspase9, but RA inhibited thisphenomenon in a dosedependent manner.

Next, we confirm whether RA inhibit the caspase-9 activation, we used caspase- 9 assay. As shown Fig. $2 \mathrm{~B}, \mathrm{Cd}^{2+}$ induced the caspase- 9 activation, these increase level was inhibited by the treatment of RA.

\section{The effect of RA on ERK activation in HEI-OC1 cell lines}

Previous study showed that the ERK inhibitor effectively suppressed cell death induced by $\mathrm{Cd}^{2+}$. (Kim et al., 2008) From this result, we can presuppose that $\mathrm{Cd}^{2+}$-induced apoptosis occurs through ERK activation. To investigate the regulatory effect of RA on activation of ERK, Western blot analysis was performed. As shown Fig. 3, we showed that the pretreatment of RA inhibited the ERK activation in auditory cells.

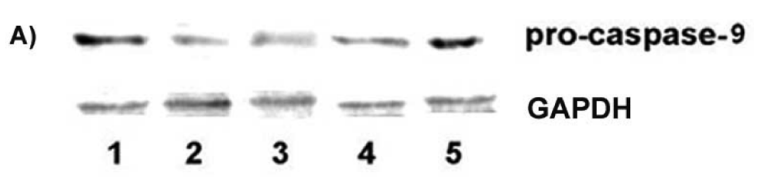

B)

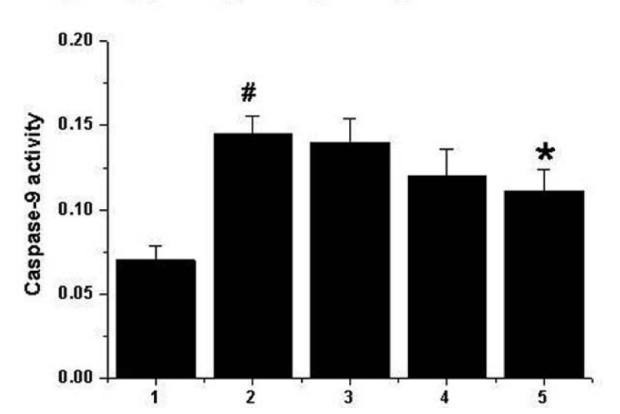

Fig. 2. The Effect of $\mathrm{RA}$ on $\mathrm{Cd}^{2+}$-induced caspase-9 activation. A) Cells $\left(5 \times 10^{6} /\right.$ well $)$ were treated with various concentrations of RA $(1-100 \mathrm{mM})$ for $2 \mathrm{~h}$ and then stimulated with $\mathrm{Cd}^{2+}(10 \mathrm{mM})$ for $24 \mathrm{~h}$. The protein extracts were assayed by Western blot analysis for procaspase-9. GAPDH was used for loading conrol. B) Cells $\left(3 \times 10^{6} /\right.$ well $)$ were treated with various concentrations of RA $(1-100 \mathrm{mM})$ for $2 \mathrm{~h}$ and then stimulated with $\mathrm{Cd}^{2+}(10 \mathrm{mM})$ for $24 \mathrm{~h}$. Caspase-9 activity was determined by a colorimetric kit using substrates. 1) Control; 2) $\mathrm{Cd}^{2+}$ treatment; 3$) \mathrm{RA}(1 \mathrm{mM})$ $\left.\left.+\mathrm{Cd}^{2+} ; 4\right) \mathrm{RA}(10 \mathrm{mM})+\mathrm{Cd}^{2+} ; 5\right) \mathrm{RA}(100 \mathrm{mM})+\mathrm{Cd}^{2+}$. ${ }^{\#} P<0.05$, significantly different from not-treated cells. ${ }^{\#} P<0.05$, significantly different from $\mathrm{Cd}^{2+}$ untreated cells. ${ }^{*} P<0.05$, significantly different from $\mathrm{Cd}^{2+}$ alonetreated cells.

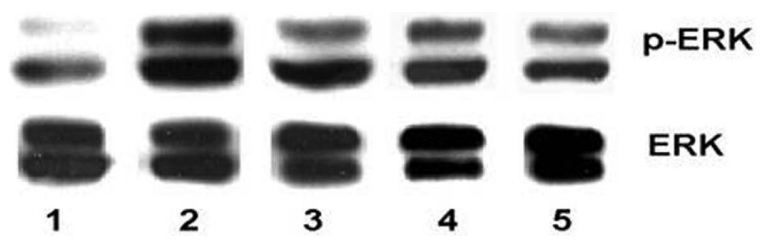

Fig. 3. The Effect of RA on ERK activation. Cells $(5 \times$ $10^{6}$ / well) were treated with various concentrations of RA (1 - $100 \mathrm{mM})$ for $2 \mathrm{~h}$ and then stimulated with $\mathrm{Cd}^{2+}(10 \mathrm{mM})$ for $24 \mathrm{~h}$, and then the phosphorylation of ERK was determined by Western blot analysis using specific anti-phospho-MAPKs. 1) Control; 2) $\mathrm{Cd}^{2+}$ treatment; 3) RA $\left.(1 \mathrm{mM})+\mathrm{Cd}^{2+} ; 4\right) \mathrm{RA}(10 \mathrm{mM})+$ $\mathrm{Cd}^{2+}$; 5) RA $(100 \mathrm{mM})+\mathrm{Cd}^{2+}$.

\section{DISCUSSION}

RA is a naturally occurring phenolic compound and it contributes to the beneficial and healthpromoting effects of herbs (D'Amelio, 1999). This compound is also known to possess marked 
antioxidant properties, (Kosar et al., 2008), antiinfl amatory (Osakabe et al., 2004), antiangiogenic (Huang and Zheng, 2006), antitumor (McKay and Blumberg, 2006), antineurodegenerative (Lee et al., 2008). However, the protective effect of RA on the auditory system is not completely elucidated. The findings herein show that antioxidant prevent the ototoxicity induced by $\mathrm{Cd}^{2+}$. These results are expected to improve the understanding of the pharmacological mechanism and potential treatments for $\mathrm{Cd}^{2+}$-induced ototoxicity.

$\mathrm{Cd}^{2+}$ is a nonessential element widely used in industry, and is also found as a contaminant in agricultural products. $\mathrm{Cd}^{2+}$ contamination of soil and water have raised concern, because this metal is bioaccumulated in the upper levels of the food chain, including in humans, in which its biological half-life is appoproximately 20 years (Satarug et al., 2003). Given its current rate of release into the environment, $\mathrm{Cd}^{2+}$ content in the human body is likely to increase in the future (Satarug et al., 2003), which could lead to a higher incidence of $\mathrm{Cd}^{2+}$-related diseases. Liver and kidney have traditionally been considered the main targets of $\mathrm{Cd}^{2+}$ toxicity (Horiguchi, et al., 2006; Nishijo et al., 2006). However, recent reports indicate that chronic exposure to low doses of $\mathrm{Cd}^{2+}$ may cause neurobehavioral problems in humans and other animals, despite a lack of detectable renal damage. These observations emphasize the importance of studying the effects of $\mathrm{Cd}^{2+}$ in other organs. Recently, it was reported that hair cells are more sensitive to cadmium than kidney tubule cells, and that the cochlear component of hearing is more vulnerable to cadmium toxicity than other parts of the auditory system.

Mitochondria factors such as cyt $c$, mediate the activation of pro-apoptotic proteases known as caspases. Activation of caspases-9 plays a central role in the execution-phase of cell apoptosis. After mitochondrial outer membrane permeabilization, intermembrane space proteins including cyt $c$ are released to activate caspases in the cytoplasm. Cell death initiated by caspase activation is considered to be the "classic" apoptotic pathway. Caspases, which are a family of cysteine-dependent aspartatedirected proteases, play important roles in initiating and executing apoptosis. Some studies strongly suggest that caspases play a key role in $\mathrm{Cd}^{2+}-$ induced cell death (Kim et al., 2000; Li et al., 2000; Kondoh et al., 2002). Previously, we showed that the apoptosis mechanism of $\mathrm{Cd}^{2+}$ in auditory cells might occur, at least in part, through a caspasedependent pathway (Kim et al., 2008). Taken together, we supposed that the caspase- 9 could be an effective target for anti-apoptotic therapy in auditory cells. Therefore, we investigated whether RA affects the cyt $c$ release, and caspase- 9 activation in induced by $\mathrm{Cd}^{2+}$. We showed that RA abrogated $\mathrm{Cd}^{2+}$-induced cyt $c$ release, and caspase- 3 activation. These results demonstrate that the anti-apoptotic effect of RA, at least in part, might be derived through the regulation of the mitochondria pathway such as cyt $c$, and caspase-9.

MAPKs pathways are central components of the intracellular signaling networks that control many aspects of mammalian cellular physiology including cell proliferation, differentiation, and apoptosis. In general, the ERK cascade is activated by growth factors and is associated with cell survival and proliferation (Lewis, et al., 1998; Puddicombe et al., 2000). On the other hand, p38 and JNK are mainly activated by cellular stress and are often associated with inflammation and apoptosis. However, cumulative reports have indicated that these signaling pathways exhibit more complex roles in the regulation of distinct cellular effects. The cellular functions regulated by ERK, p38 or JNK seem to depend on the cell type, the stimulus, the duration and strength of kinase activities (Nebreda and Porras, 2000). We showed that RA suppressed ERK activation induced by $\mathrm{Cd}^{2+}$. These results suggest that the ERK pathway may be a potential therapeutic target to prevent ototoxic damage from $\mathrm{Cd}^{2+}$. Although RA attenuated ERK activation, the effect of RA on other pathways involving MAPK upstream and downstream was not elucidated in the present 
study. Thus, further investigation is necessary to clarify the role of RA on the MAPK pathway in the auditory system.

In conclusion, in the presence of $\mathrm{Cd}^{2+}$, an antioxidant counteracts the ototoxicity by suppressing the release of cyt $c$ and activation of ERK and caspase-9. These results are expected to improve the understanding of the regulatory mechanism and potential treatments for $\mathrm{Cd}^{2+}$-induced ototoxicity.

\section{ACKNOWLEDGEMENTS}

This work was supported by the Korea Research Foundation Grant funded by the Korean Government (MOEHRD)" (KRF-2006- 351- 100256A).

\section{REFERENCES}

Bertin G, Averbeck D. (2006) Cadmium: cellular effects, modifications of biomolecules, modulation of DNA repair and genotoxic consequences. Biochimie. 88, 1549-1559.

D'Amelio FS. (1999) Botanicals, a Phytocosmetic Desk Reference. CRC Press: London; 361.

De Vries W, Römkens PF, Schütze G.. (2007) Critical soil concentrations of cadmium, lead, and mercury in view of health effects on humans and animals. Rev. Environ. Contam. Toxicol. 191, 91-130.

De Martinis M, Franceschi C, Monti D, Ginaldi L. (2007) Apoptosis remodeling in immunosenescence: implications for strategies to delay ageing. Curr. Med. Chem. 14, 1389-1397.

Garrido C, Galluzzi L, Brunet M, Puig PE, Didelot C, Kroemer G. (2006) Mechanisms of cytochrome c release from mitochondria. Cell Death Differ. 13, 1423-1433.

Gatzka M, Walsh CM. (2007) Apoptotic signal transduction and T cell tolerance. Autoimmunity 40, 442-452.

Harstad EB, Klaassen CD. (2002) Tumor necrosis factoralpha-null mice are not resistant to cadmium chloride-induced hepatotoxicity. Toxicol. Appl. Pharm. 179, 155-162.

Horiguchi, H., Oguma, E., Kayama, F. (2006) Cadmium and cisplatin damage erythropoietin-producing proximal renal tubular cells. Arch. Toxicol. 80, 680-686.
Huang SS, Zheng RL. (2006) Rosmarinic acid inhibits angiogenesis and its mechanism of action in vitro. Cancer Lett. 239, 271-280.

Kalinec GM, Webster P, Lim DJ, Kalinec F. (2003) A cochlear cell line as an in vitro system for drug ototoxicity screening. Audiol. Neurootol. 8, 177-189.

Kim MS, Kim BJ, Woo HN, Kim KW, Kim KB, Kim IK, Jung YK. (2000) Cadmium induces caspasemediated cell death: suppression by Bcl-2. Toxicology 145, 27-37.

Kim JJ, Jeong HJ, Myung NY, Kim MC, Lee JH, So HS, Park RJ, Kim HM, Um JY, Hong SH. (2008) The protective mechanism of antioxidants in cadmiuminduced ototoxicity in vitro and in vivo. Environ. Health Perspect. 116, 854-62.

Kondoh M, Araragi S, Sato K, Higashimoto M, Takiguchi M, Sato M. (2002) Cadmium induces apoptosis partly via caspase-9 activation in HL-60 cells. Toxicology 170, 111-117.

Kosar M, Goger F, Can Başer KH. (2008) In vitro antioxidant properties and phenolic composition of Salvia virgata Jacq. from Turkey. J. Agric. Food Chem. 56, 2369-2374.

Lee HJ, Cho HS, Park E, Kim S, Lee SY, Kim CS, Kim do K, Kim SJ, Chun HS. (2008) Rosmarinic acid protects human dopaminergic neuronal cells against hydrogen peroxide-induced apoptosis. Toxicology 250, 109-115.

Lemarie A, Lagadic-Gossmann D, Morzadec C, Allain N, Fardel O, Vernhet L. (2004) Cadmium induces caspase-independent apoptosis in liver Hep3B cells: role for calcium in signaling oxidative stress-related impairment of mitochondria and relocation of endonuclease $\mathrm{G}$ and apoptosis-inducing factor. Free Radic. Biol. Med. 36, 1517-1531.

Lewis TS, Shapiro PS, Ahn NG. (1998) Signal transduction through MAP kinase cascades. Adv. Cancer Res. 74, 49-139.

Li M, Kondo T, Zhao QL, Li FJ, Tanabe K, Arai Y, Zhou ZC, Kasuya M. (2000) Apoptosis induced by cadmium in human lymphoma U937 cells through $\mathrm{Ca}^{2+}$-calpain and caspase-mitochondria-dependent pathways. J. Biol. Chem. 275, 39702-39709.

McKay DL, Blumberg JB. (2006) A review of the bioactivity and potential health benefits of peppermint tea (Mentha piperita L.). Phytother. Res. 20, 619-633.

Nebreda AR, Porras A. (2000) p38 MAP kinases: beyond 
the stress response. Trends Biochem. Sci. 25, 257-260. Nishijo M, Morikawa Y, Nakagawa H, Tawara K, Miura K, Kido T, Ikawa A, Kobayashi E, Nogawa K. (2006) Causes of death and renal tubular dysfunction in residents exposed to cadmium in the environment. Occup. Environ. Med. 63, 545-550.

Osakabe N, Yasuda A, Natsume M, Yoshikawa T. 2004. Rosmarinic acid inhibits epidermal inflammatory responses: anticarcinogenic eff ect of Perilla frutescens extract in the murine two-stage skin model. Carcinogenesis 25, 549-557.

Ozcaglar HU, Agirdir B, Dinc O, Turhan M, Kilincarslan S, Oner G. (2000) Effects of cadmium on the hearing system. Acta Otolaryngol. 121, 393-397.

Puddicombe, S. M., Davies, D. E. The role of MAP kinases in intracellular signal transduction in bronchial epithelium. Clin Exp Allergy. 2000, 30, 7-11.

Satarug S, Baker JR, Urbenjapol S, Haswell-Elkins M,
Reilly PE, Williams DJ, Moore MR. (2003) A global perspective on cadmium pollution and toxicity in non occupationally exposed population. Toxicol. Lett. 137, 65-83.

Scarpati ML, Oriente G. (1958) Isolamento e costituzione dell'acido rosmarinico (dal Rosmarinus off.). Ric. Sci. 28, 2329-2333.

Schaeffer, H. J., Weber, M. J. (1999) Mitogen-activated protein kinases: specific messages from ubiquitous messengers. Mol. Cell Biol. 19, 2435-2444.

Shih CM, Wu JS, Ko WC, Wang LF, Liang HF, Chen YC, et al. (2003) Mitochondria mediated caspase independent apoptosis induced by cadmium in normal human lung cells. J. Cell Biochem. 89, 335-347.

Van Heemst D, den Reijer PM, Westendorp RG. 2007. Ageing or cancer: A review On the role of caretakers and gatekeepers. Eur. J. Cancer 43, 2144-2152. 